\title{
Core binding factor acute myeloid leukaemia and c-KIT mutations
}

\author{
LUDOVICA RIERA $^{1,2}$, FILIPPO MARMONT ${ }^{3}$, DANIELA TOPPINO ${ }^{2}$, CHIARA FRAIRIA $^{3}$, \\ FRANCESCA SISMONDI $^{1,2}$, ERNESTA AUDISIO ${ }^{3}$, CRISTIANA DI BELLO $^{2}$, \\ STEFANO D'ARDIA ${ }^{3}$, PAOLA FRANCIA DI CELLE ${ }^{2}$, EMANUELA MESSA $^{3}$, \\ GIORGIO INGHIRAMI ${ }^{1,2}$, UMBERTO VITOLO ${ }^{3}$ and ACHILLE PICH ${ }^{1}$ \\ ${ }^{1}$ Department of Molecular Biotechnology and Health Sciences, Section of Pathology, University of Turin; \\ ${ }^{2}$ Center for Experimental Research and Medical Studies (CeRMS), University of Turin; \\ ${ }^{3}$ Department of Haematology, Azienda Ospedaliera Città della Salute e della Scienza, Turin, Italy
}

Received December 10, 2012; Accepted February 11, 2013

DOI: $10.3892 /$ or.2013.2328

\begin{abstract}
Core binding factor (CBF) acute myeloid leukaemia (AML) represents $5-8 \%$ of all AMLs and has a relatively favourable prognosis. However, activating c-KIT mutations are reported to be associated with higher risk of relapse and shorter survival. To verify the incidence and prognostic value of c-KIT mutations in CBF AML, we retrospectively analysed bone marrow samples of 23 consecutive adult patients with de novo CBF AML [14 inv(16) and $9 \mathrm{t}(8 ; 21)]$ treated at a single institution from 2000 to 2011. All patients received standard induction chemotherapy with cytarabine, idarubicin and etoposide; 13 underwent allogeneic stem cell transplantation. c-KIT mutations in exons 8, 9, 10, 11, 13, 14 and 17 were assessed by PCR amplification in combination with direct sequencing. c-KIT mutations ( 3 in exon 10 and 4 in exon 17) were detected in $7 / 23(30.4 \%)$ patients, 3 with $t(8 ; 21)$ and 4 with inv(16). No difference in c-KIT mutation status was observed between cases with inv(16) or $\mathrm{t}(8 ; 21)$ alone and cases with additional cytogenetic abnormalities. No association between gender, age, white blood cell and platelet count, peripheral blood and bone marrow blast cells at diagnosis, achievement of complete remission, cytogenetic risk groups and Wilms tumour gene 1 (WT1) levels was found. On the contrary, lactate dehydrogenase $(\mathrm{LDH})$ values were higher in mutated than in non-mutated patients $(\mathrm{P}=0.01)$. Overall survival $(\mathrm{OS})$ rates were longer in $\mathrm{CBF}$ compared to the other types of AML and disease-free survival (DFS) was longer in inv(16) than in $t(8 ; 21)$ AML. OS and DFS were similar in mutated and non-mutated CBF AML patients. Our results confirm a better prognosis for CBF AML than all other AML categories, and for inv(16) than $t(8 ; 21)$ AML. However, no prognostic value for c-KIT mutational
\end{abstract}

Correspondence to: Professor Achille Pich, Department of Molecular Biotechnology and Health Sciences, Section of Pathology, University of Turin, Via Santena 7, I-10126 Turin, Italy

E-mail: achille.pich@unito.it

Key words: acute myeloid leukaemia, core binding factor, c-KIT mutations, lactate dehydrogenase, prognosis status was found in our series. The association between LDH levels and c-KIT mutation would indicate a more active proliferation for mutated CBF AML.

\section{Introduction}

RUNX1-RUNX1T1 [t(8;21)] or CBFB-MYH11 [inv(16)] fusion transcripts identify the core binding factor (CBF) acute myeloid leukaemia (AML). Both $\mathrm{t}(8 ; 21)$ and inv(16) are characterised at the molecular level by disruption of genes encoding different subunits of CBF (1). CBF AML represents $5-8 \%$ of all AML (2) and has a relatively favourable prognosis, following treatment with high dose cytarabine in the consolidation phase (3-5). Mutations of c-KIT occur in 20-25\% of $\mathrm{t}(8 ; 21)$ and in approximately $30 \%$ of inv(16) cases (6). In CBF AML, c-KIT mutations occur frequently within exon 17 , which encodes the activation loop in the kinase domain, and in exon 8 , which encodes the extracellular portion of the KIT receptor (7). Older age, CD56 expression and activating c-KIT mutations are reported to be associated with higher incidence of relapse and lower survival $(6,8,9)$ while inv(16) patients with +22 secondary abnormality have a better prognosis $(10,11)$. However, no significant differences in overall survival (OS) rates according to c-KIT mutation status have been reported in CBF AML patients (12). In the present study, we retrospectively analysed 23 patients with CBF AML in order to investigate the incidence and prognostic value of c-KIT mutations.

\section{Materials and methods}

Patients. Two hundred and forty-nine consecutive unselected adult patients with newly diagnosed AML were admitted to the Division of Haematology, Città della Salute e della Scienza, University of Turin, Italy, from 2000 to 2011. Among these, 23 patients (12 female and 11 male) with de novo CBF AML were retrospectively examined. The mean age was 42.7 years (range, 19-64). Diagnosis of CBF AML was performed according to the WHO criteria (2). Inv(16) was present in 14 patients $(60.8 \%)$, 9 with isolated inv(16) and 5 with additional cytogenetic abnormalities. Nine patients (39.2\%) showed $\mathrm{t}(8 ; 21) ; 7$ had isolated $\mathrm{t}(8 ; 21)$ and $2 \mathrm{t}(8 ; 21)$ 
Table I. Primer sequences for mutation analysis.

Sequences

\begin{tabular}{ll}
\hline FLT3 ITD & F: TGTCGAGCAGTACTCTAAACA \\
& R: ATCCTAGTACCTTCCCAAACTC \\
FLT3 D835 & F: CCGCCAGGAACGGCTTG \\
& R: GCAGACGGGCATTGCCCC \\
NPM-I11f-FAM & GTGGTAGAATGAAAAATAGAT \\
NPM-E12r & CTTGGCAATAGAACCTGGAC \\
NPM1 & F: TGGTTCTCTTCCCAAAGTGG \\
& R: CCTGGACAACATTTATCAAACACG \\
CK9 & F: TCCTAGAGTAAGCCAGGGCTT \\
& R: TGGTAGACAGAGCCTAAACATCC \\
CK11 & F: CCAGAGTGCTCTAATGACTG \\
& R: AGCCCCTGTTTCATACTGAC \\
CK13 & F: GCTTGACATCAGTTTGCCAG \\
& R: AAAGGCAGCTTGGACACGGCTTTA \\
CK17 & F: TGAACATCATTCAAGGCGTACTTTG \\
& R:TTGAAACTAAAAATCCTTTCAGGAC \\
CK14 & F: TCTCACCTTCTTTCTAACCTTTTC \\
& R: AACCCTTATGACCCCATGAA \\
KIT10 & F: TGCCAAAGTTTGTGATTCCA \\
& R: GTGGGGAGAAAGGGAAAAAT \\
CKIT8 & F: GCAGCCTCAGGAAGGTTGTA \\
& R: AATTGCAGTCCTTCCCCTCT \\
\hline
\end{tabular}

F, forward; R, reverse.

with additional cytogenetic aberrations. All patients received standard induction chemotherapy with cytarabine, idarubicin and etoposide (ICE), followed by consolidation treatment with high-dose cytarabine. Thirteen patients with suitable HLA matched donors (related or unrelated) underwent allogeneic stem cell transplantation in first (10 cases) or second (3 cases) remission. To avoid confounding effect of the transplant procedure, patients were censored at the time of the transplantation. General informed consent was obtained according to the local Ethics Committee guidelines. Samples were numerically identified, maintaining patient anonymity.

Molecular analysis. c-KIT mutations in exons 8, 9, 10, 11, 13, 14 and 17 were assessed by polymerase chain reaction (PCR) amplification in combination with direct sequencing from bone marrow (BM) samples.

Amplification of c-KIT exons was performed by PCR with specific oligonucleotide primers (Table I) (13-15), and DNA sequencing was executed using the cDNA from AML BM samples. Sequencing reactions were carried out using the BigDye Terminator Cycle Sequencing Ready Reaction kit (Applied Biosystems, Foster City, CA, USA), and the analysis was performed on an ABI 3130 automated capillary system. FLT3-ITD and D835 mutation status was determined by conventional PCR and direct sequencing (16) and NPM1

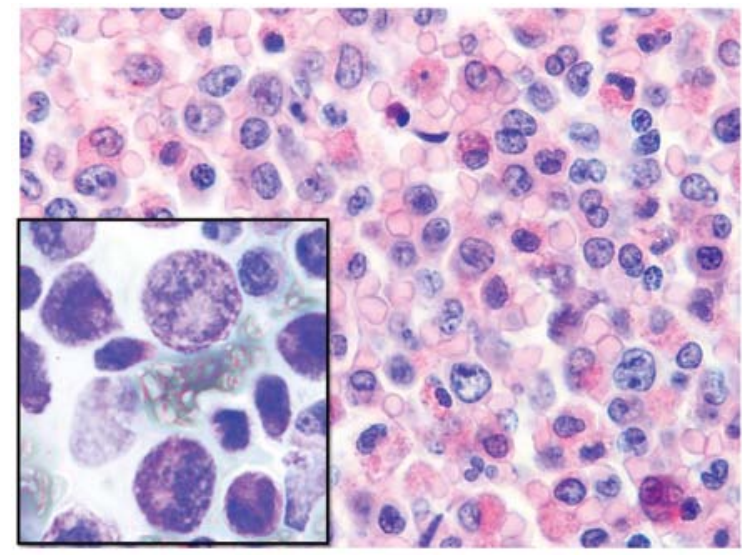

Figure 1. Inv(16) AML (FAB M4 Eo). Bone marrow biopsy (Dominici's staining, x600) showing proliferation of both neutrophil and monocyte precursors, and abnormal eosinophils with basophilic granules. (Inset, Giemsa staining, $\mathrm{x} 1,000)$

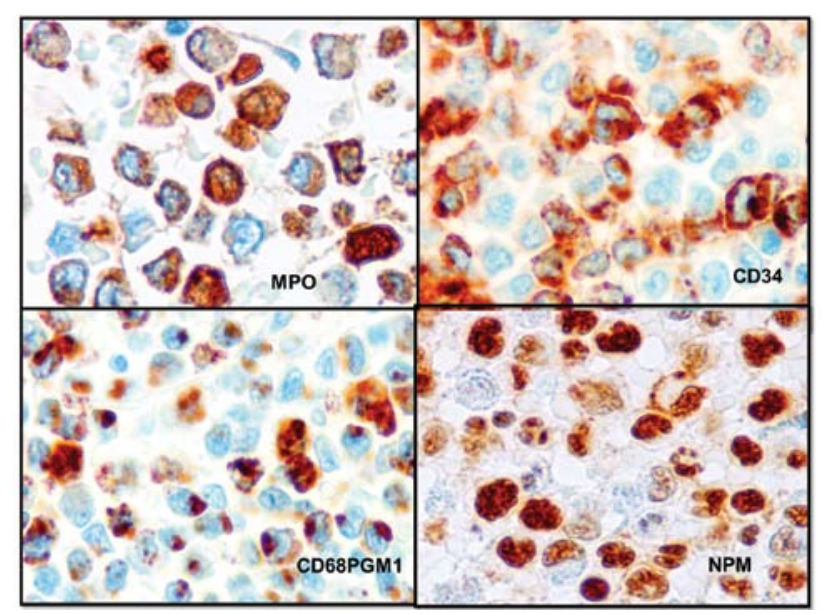

Figure 2. Inv(16) AML. Blasts expressing MPO, CD34, CD68PGM1 and intranuclear NPM. (Bone marrow biopsy; immunoperoxidase staining, x600).

mutation status was determined by PCR-capillary electrophoresis methods (17), followed by direct sequencing for positive sample characterization (18) (primers in Table I). The electropherograms were compared to published germ-line sequences using basic local alignment search tool (BLAST) on the Internet. Wilms tumour gene 1 (WT1) expression was quantified using a real-time quantitative PCR (WT1 ELN kit, Nanogen, Buttigliera Alta, Turin, Italy).

Histology. Formalin-fixed, paraffin-embedded BM biopsies were stained with H\&E, Dominici, Perls, reticulin and immunostained with monoclonal antibodies anti-CD2, CD13, CD33, CD34, CD56 (all from Novocastra, Newcastle, UK), anti-human nucleophosmin, CD68PGM1, and polyclonal antibodies anti-human myeloperoxidase and CD117 (all from Dako, Glostrup, Denmark) (Figs. 1 and 2).

Statistical analysis. The association between c-KIT mutation and clinical or haematological parameters was assessed by the one-way analysis of variance (ANOVA) and the Fisher's exact test. Univariate survival analyses were based on Kaplan-Meier 
Table II. c-KIT mutations observed in 23 CBF AML cases.

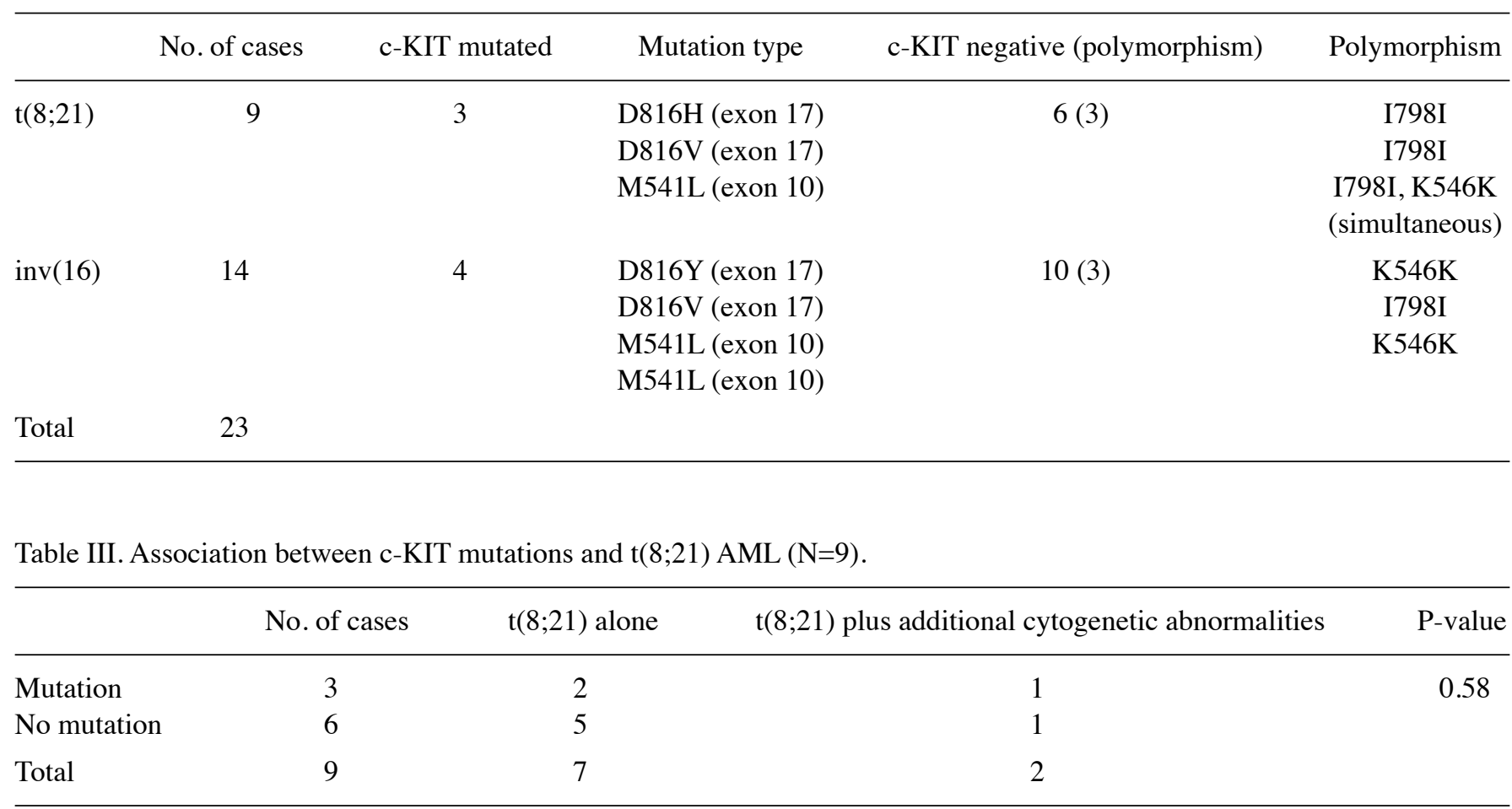

Table IV. Association between c-KIT mutations and inv(16) AML (N=14).

\begin{tabular}{lcccc}
\hline & No. of cases & inv(16) alone & inv(16) plus additional cytogenetic abnormalities & P-value \\
\hline Mutation & 4 & 2 & 2 & 0.45 \\
No mutation & 10 & 7 & 5 & 5 \\
Total & 14 & 9 & 5 \\
\hline
\end{tabular}
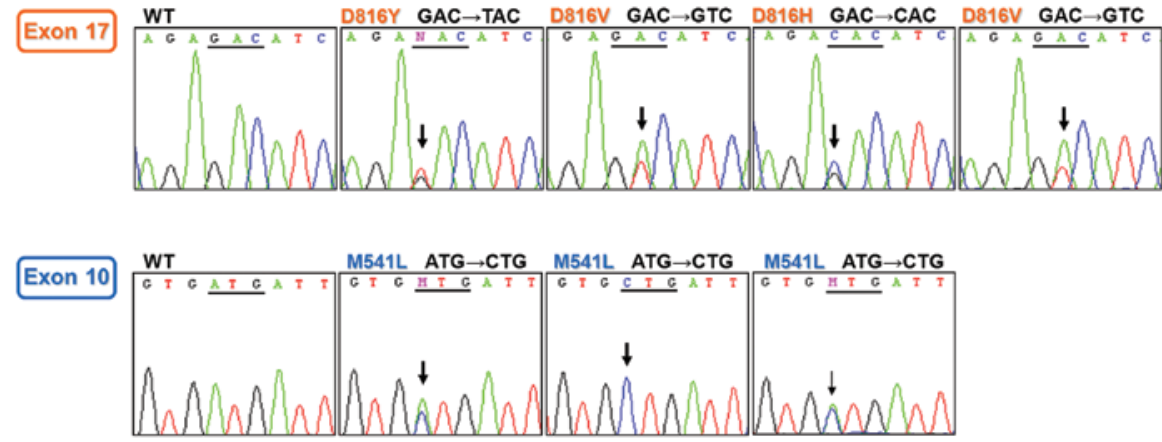

Figure 3. c-KIT mutation electropherograms. Representation of peaks corresponding to wild-type (wt) and mutant c-KIT alleles (indicated by arrows) in chromatograms of cDNA from leukaemic cells of the seven mutated cases in exon 10 or 17 . Wt sequences of control cases are also reported.

product-limit estimates of survival distribution, and differences between survival curves were tested using the Cox-Mantel test.

\section{Results}

c-KIT mutations were detected in 7/23 (30.4\%) patients. M541L mutation (exon 10) was found in 3 samples and D816V or D816H or D816Y mutation (exon 17) in 4. Two SNPs (K546K and I798I) were detected in 6 AML samples (Table II). c-KIT mutation electropherograms are shown in Fig. 3. FLT3 ITD, FLT3 D835 and NPM1 mutations rarely occurred (data not shown).

Association between c-KIT mutation and clinical and haematological characteristics. c-KIT mutations were detected in $3 / 9(33.3 \%)$ patients with $\mathrm{t}(8 ; 21)$ and in $4 / 14(28.6 \%)$ patients with inv(16). No significant difference in c-KIT mutation was 
Table V. Association between c-KIT mutation and clinical and haematological characteristics in CBF AML (N=23).

\begin{tabular}{|c|c|c|c|c|}
\hline \multirow[b]{2}{*}{ Variables } & \multirow[b]{2}{*}{ No. of cases } & \multirow{2}{*}{$\frac{\mathrm{c}-\text { KIT mutated }(\mathrm{n}=7)}{\text { Mean } \pm \mathrm{SD}}$} & \multirow{2}{*}{$\frac{\mathrm{c}-\mathrm{KIT} \text { non mutated }(\mathrm{n}=16)}{\text { Mean } \pm \mathrm{SD}}$} & \multirow[b]{2}{*}{$\mathrm{P}$-value } \\
\hline & & & & \\
\hline Age (years) & 23 & $51 \pm 11.2$ & $39 \pm 13.4$ & 0.06 \\
\hline WBC count $\left(\mathrm{x} 10^{9} / 1\right)$ & 23 & $34.045 \pm 33.9$ & $21.702 \pm 19.918$ & 0.3 \\
\hline Plt count $\left(\times 10^{9} / 1\right)$ & 23 & $30.428 \pm 31.320$ & $46.133 \pm 24.023$ & 0.2 \\
\hline LDH (UI/l) & 23 & $1,386 \pm 629$ & $753 \pm 312$ & 0.01 \\
\hline PB blasts (\%) & 23 & $48.43 \pm 23.04$ & $54.92 \pm 19.67$ & 0.5 \\
\hline BM blasts $(\%)$ & 23 & $48.85 \pm 24.88$ & $60.64 \pm 14.25$ & 0.17 \\
\hline WT1 (number of WT1 copies/104 ABL copies) & 15 & $17,307 \pm 22,628(4)$ & $15,687 \pm 17,780(11)$ & 0.8 \\
\hline \multicolumn{5}{|l|}{ Gender } \\
\hline Male & 11 & $3 / 7$ & $8 / 16$ & \\
\hline Female & 12 & $4 / 7$ & $8 / 16$ & 0.5 \\
\hline \multicolumn{5}{|l|}{ Cytogenic risk } \\
\hline Low & 18 & $6 / 7$ & $12 / 16$ & \\
\hline High & 5 & $1 / 7$ & $4 / 16$ & 0.5 \\
\hline \multicolumn{5}{|l|}{ Remission } \\
\hline Complete remission & 21 & 7/7 & $14 / 16$ & \\
\hline No remission & 2 & $0 / 7$ & $2 / 16$ & 0.5 \\
\hline
\end{tabular}

WBC, white blood cell; Plt, platelet; LDH, lactate dehydrogenase; PB, peripheral blood; BM, bone marrow; WT1, Wilms tumour gene.

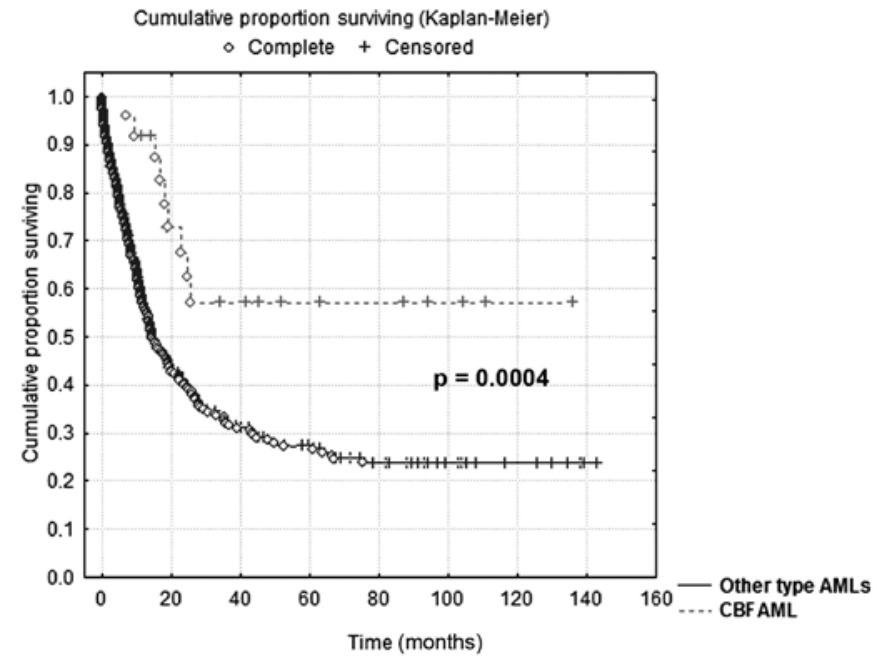

Figure 4. Overall survival of patients with CBF AML and other types of AML.

found between cases with $\mathrm{t}(8 ; 21)$ or inv(16) alone and cases with additional cytogenetic aberrations (Tables III and IV).

c-KIT mutation status was not associated with gender, age, white blood cell and platelet count, percentage of peripheral blood and bone marrow blasts at diagnosis, cytogenetic risk groups and WT1 levels. Also, no association was found for the achievement of complete remission (CR), although the two patients who did not achieve CR were non-mutated. On the contrary, lactate dehydrogenase (LDH) levels were higher (1386 UI/l) in c-KIT mutated than in non-mutated patients (753 UI/1; P=0.01) (Table V).

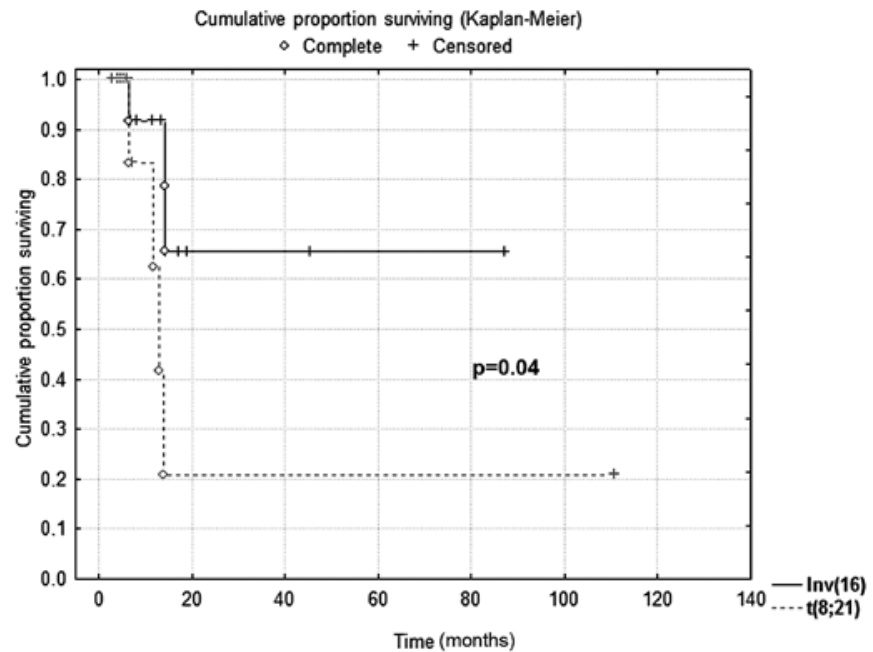

Figure 5. Disease-free survival for patients with inv(16) and $t(8 ; 21)$ AML.

Correlation of c-KIT mutation with overall and disease-free survival. In the $23 \mathrm{CBF}$ AML patients OS was significantly longer than in the 226 patients with other types of AML treated at the same institution during the same period; at the 10-year follow-up, 57\% of CBF AML patients were alive compared to $24 \%$ of patients with all other AML categories $(\mathrm{P}=0.0004)$ (Fig. 4).

No difference in OS was found between inv(16) and $\mathrm{t}(8 ; 21)$ CBF AML; after 88 months, $76 \%$ of inv(16) and $60 \%$ of $\mathrm{t}(8 ; 21)$ patients were alive, respectively $(\mathrm{P}=0.6)$. However, DFS for inv(16) AML was significantly longer than that for $t(8 ; 21)$ 


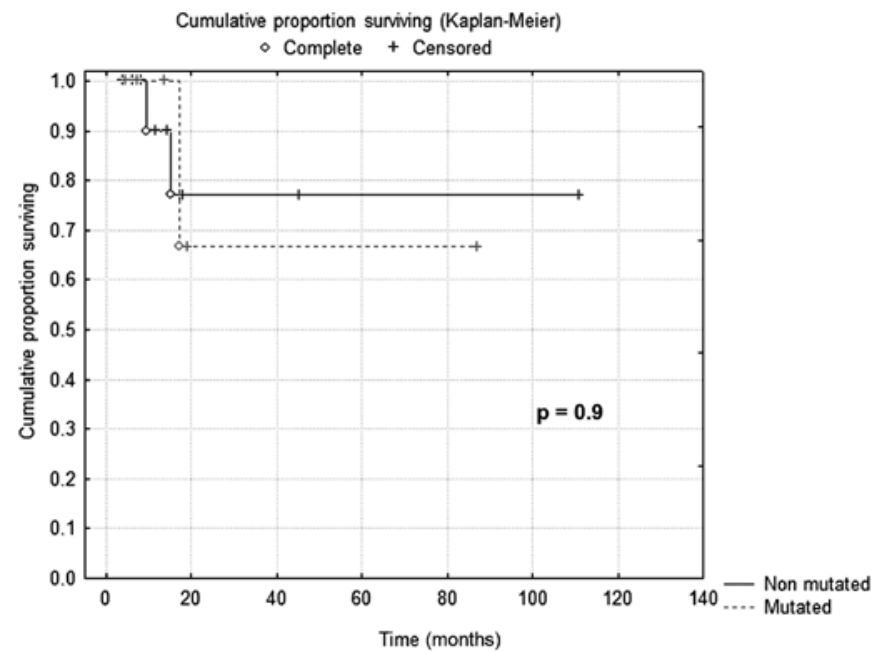

Figure 6. Kaplan-Meier overall survival curves for patients with CBF AML categorised according to c-KIT mutation.

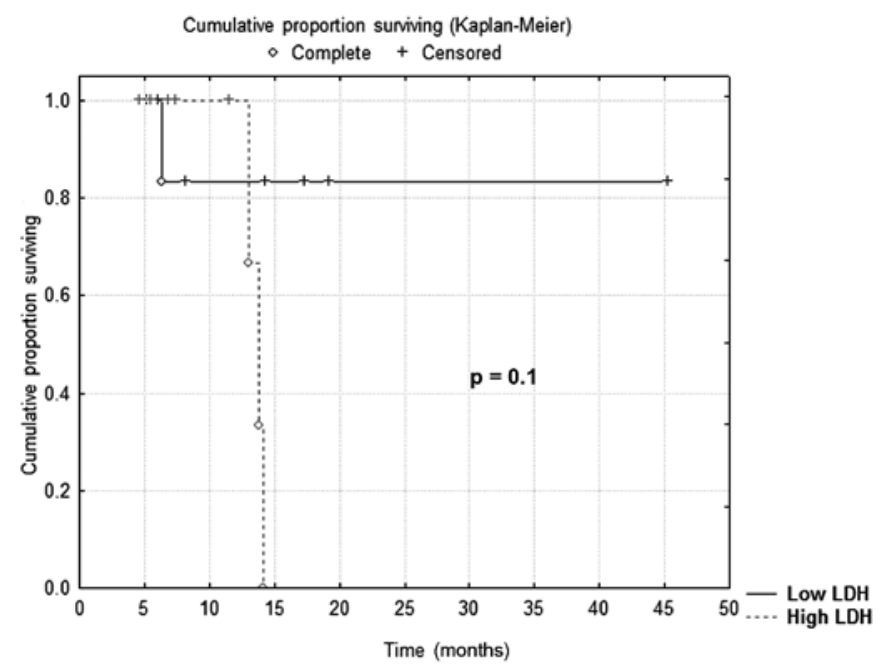

Figure 7. Kaplan-Meier disease-free survival curves for CBF AML patients categorised according to the median LDH value.

cases; after 88 months, $67 \%$ of inv(16) patients were free of the disease, vs. $20 \%$ of those with $\mathrm{t}(8 ; 21)(\mathrm{P}=0.04)$ (Fig. 5).

No difference in OS was found when CBF AML patients were categorised according to c-KIT mutation; after 88 months, $78 \%$ of c-KIT non-mutated and $68 \%$ of mutated patients were alive, respectively ( $\mathrm{P}=0.9)$ (Fig. 6). DFS was similar in c-KIT mutated and non-mutated CBF AML patients $(\mathrm{P}=0.6)$.

\section{Discussion}

Our results showed an overall incidence of c-KIT mutation in $30.4 \%$ of cases, as previously reported in adult CBF AML (6), and a better prognosis for CBF AML than for cytogenetically normal or other subtypes of AML, which is in agreement with previous data $(19,20)$. In our study, inv(16) AML had a significantly longer DFS than $t(8 ; 21)$ AML, consistent with previous reports demonstrating that patients with $t(8 ; 21)$ have significantly shorter survival times after relapse than patients with inv(16), possibly related to a lower response to salvage treatment in patients with $\mathrm{t}(8 ; 21)(10,11,21)$.

c-KIT mutations in our CBF AMLs were associated with higher LDH levels, suggesting a possible prognostic role. It is well known that high LDH values are associated with a poorer outcome both in AML and myelodysplastic syndromes (MDS) (22-24). This was observed in our study as well; when cases were categorised according to the median LDH value (880 UI/l), all patients with higher LDH values relapsed after 15 months, while $84 \%$ of patients with lower LDH values were free of the disease. However, possibly due to the small number of cases, the result is only of borderline significance $(\mathrm{P}=0.1)$ (Fig. 7). The association between c-KIT mutation and $\mathrm{LDH}$ levels is likely to indicate a more active proliferation in mutated CBF AML.

Contrary to most published studies, no association was found in our CBF AML group between c-KIT mutations and achievement of CR, OS and DFS; this may be due to the small number of cases and to considering CBF AML as a single group. Indeed, previous reports showed a prognostic value of c-KIT mutations in $\mathrm{t}(8 ; 21)$ but not in inv(16) CBF AML $(7,25)$. Therefore, $\mathrm{t}(8 ; 21)$ and inv(16) AML should be regarded as distinct clinical entities to be stratified and reported separately, as already suggested (11), and possibly treated with a tailored approach (26).

Therefore, further studies are required to clarify the prognostic value of c-KIT mutations in newly diagnosed adult AML.

\section{Acknowledgements}

This study was supported by grants from the Italian Ministero dell'Università e Ricerca Scientifica e Tecnologica (MURST).

\section{References}

1. Speck NA and Gilliland DG: Core-binding factors in haematopoiesis and leukaemia. Nat Rev Cancer 2: 502-513, 2002.

2. Arber DA, Brunning RD, Le Beau MM, Falini B, Vardiman JW, Porwit A, Thiele J and Bloomfield CD: Acute myeloid leukaemia with recurrent genetic abnormalities. In: WHO Classification of Tumours of Haematopoietic and Lymphoid Tissues. Swerdlow SH, Campo E, Harris NL, Jaffe ES, Pileri S, Stein H, Thiele J and Vardiman JW (eds). 4th edition. IARC Press, Lyon, pp110-112, 2008.

3. Mrózek K, Heinonen K, Lawrence D, Carroll AJ, Koduru PR, Rao KW, Strout MP, Hutchison RE, Moore JO, Mayer RJ, Schiffer CA and Bloomfield CD: Adult patients with de novo acute myeloid leukemia and $t(9 ; 11)(p 22 ; q 23)$ have a superior outcome to patients with other translocations involving band 11q23: a Cancer and Leukemia Group B Study. Blood 90: 4532-4538, 1997.

4. Bloomfield CD, Lawrence D, Byrd JC, Carroll A, Pettenati MJ, Tantravahi R, Patil SR, Davey FR, Berg DT, Schiffer CA, Arthur DC and Mayer RJ: Frequency of prolonged remission duration after high-dose cytarabine intensification in acute myeloid leukemia varies by cytogenetic subtype. Cancer Res 58: 4173-4179, 1998.

5. Grimwade D, Walker H, Oliver F, Wheatley K, Harrison C, Harrison G, Rees J, Hann I, Stevens R, Burnett A and Goldstone A: The importance of diagnostic cytogenetics on outcome in AML: analysis of 1,612 patients entered into the MRC AML 10 trial. The Medical Research Council Adult and Children's Leukaemia Working Parties. Blood 92: 2322-2333, 1998.

6. Paschka P, Marcucci G, Ruppert AS, Mrózek K, Chen H, Kittles RA, Vukosavljevic T, Perrotti D, Vardiman JW, Carroll AJ, Kolitz JE, Larson RA and Bloomfield CD; Cancer and Leukemia Group B: Adverse prognostic significance of KIT mutations in adult acute myeloid leukemia with inv(16) and $\mathrm{t}(8 ; 21)$ : a Cancer and Leukemia Group B Study. J Clin Oncol 24: 3904-3911, 2006 
7. Park SH, Chi HS, Min SK, Park BG, Jang S and Park CJ: Prognostic impact of c-KIT mutations in core binding factor acute myeloid leukemia. Leuk Res 35: 1376-1383, 2011.

8. Baer MR, Stewart CC, Lawrence D, Arthur DC, Byrd JC, Davey FR, Schiffer CA and Bloomfield CD: Expression of the neural cell adhesion molecule CD56 is associated with short remission duration and survival in acute myeloid leukemia with $\mathrm{t}(8 ; 21)(\mathrm{q} 22 ; \mathrm{q} 22)$. Blood 90: 1643-1648, 1997.

9. Delaunay J, Vey N, Leblanc T, Fenaux P, Rigal-Huguet F, Witz F, Lamy T, Auvrignon A, Blaise D, Pigneux A, Mugneret F, Bastard C, Dastugue N, Van den Akker J, Fière D, Reiffers J, Castaigne S, Leverger G, Harousseau JL and Dombret H; French Acute Myeloid Leukemia Intergroup; Groupe Ouest-Est des Leucémies Aiguës Myéoblastiques; Leucémies Aiguës Myéoblastiques de l'Enfant; Acute Leukemia French Association; Bordeaux-Grenoble-Marseille-Toulouse cooperative groups: Prognosis of inv $(16) / t(16 ; 16)$ acute myeloid leukemia (AML): a survey of 110 cases from the French AML Intergroup. Blood 102 462-469, 2003

10. Schlenk RF, Benner A, Krauter J, Büchner T, Sauerland C, Ehninger G, Schaich M, Mohr B, Niederwieser D, Krahl R, Pasold R, Döhner K, Ganser A, Döhner H and Heil G: Individual patient data-based meta-analysis of patients aged 16 to 60 years with core binding factor acute myeloid leukemia: a survey of the German Acute Myeloid Leukemia Intergroup. J Clin Oncol 22: 3741-3750, 2004

11. Marcucci G, Mrózek K, Ruppert AS, Maharry K, Kolitz JE, Moore JO, Mayer RJ, Pettenati MJ, Powell BL, Edwards CG, Sterling LJ, Vardiman JW, Schiffer CA, Carroll AJ, Larson RA and Bloomfield CD: Prognostic factors and outcome of core binding factor acute myeloid leukemia patients with $\mathrm{t}(8 ; 21)$ differ from those of patients with inv(16): a Cancer and Leukemia Group B study. J Clin Oncol 23: 5705-5717, 2005.

12. Marková J, Marková J, Trnková Z, Michková P, Maaloufová J, Starý J, Cetkovský P and Schwarz J: Monitoring of minimal residual disease in patients with core binding factor acute myeloid leukemia and the impact of C-KIT, FLT3, and JAK2 mutations on clinical outcome. Leuk Lymphoma 50: 1448-1460, 2009.

13. Lasota J, Wozniak A, Sarlomo-Rikala M, Rys J, Kordek R, Nassar A, Sobin LH and Miettinen M: Mutations in exons 9 and 13 of KIT gene are rare events in gastrointestinal stromal tumors. A study of 200 cases. Am J Pathol 157: 1091-1095, 2000.

14. Rubin BP, Singer S, Tsao C, Duensing A, Lux ML, Ruiz R, Hibbard MK, Chen CJ, Xiao S, Tuveson DA, Demetri GD, Fletcher CD and Fletcher JA: KIT activation is a ubiquitous feature of gastrointestinal stromal tumors. Cancer Res 61: 8118-8121, 2001.

15. Miselli FC, Casieri P, Negri T, Orsenigo M, Lagonigro MS, Gronchi A, Fiore M, Casali PG, Bertulli R, Carbone A, Pierotti MA, Tamborini E and Pilotti S: c-Kit/PDGFRA gene status alterations possibly related to primary imatinib resistance in gastrointestinal stromal tumors. Clin Cancer Res 13 2369-2377, 2007.
16. Kottaridis PD, Gale RE and Linch DC: Flt3 mutations and leukaemia. Br J Haematol 122: 523-538, 2003.

17. Thiede C, Koch S, Creutzig E, Steudel C, Illmer T, Schaich M and Ehninger G: Prevalence and prognostic impact of NPM1 mutations in 1485 adult patients with acute myeloid leukemia (AML). Blood 107: 4011-4020, 2006.

18. Verhaak RG, Goudswaard CS, van Putten W, Bijl MA, Sanders MA, Hugens W, Uitterlinden AG, Erpelinck CA Delwel R, Löwenberg B and Valk PJ: Mutations in nucleophosmin (NPM1) in acute myeloid leukemia (AML): association with other gene abnormalities and previously established gene expression signatures and their favorable prognostic significance. Blood 106: 3747-3754, 2005.

19. Gulley ML, Shea TC and Fedoriw Y: Genetic tests to evaluate prognosis and predict therapeutic response in acute myeloid leukemia (Review). J Mol Diagn 12: 3-16, 2010.

20. Sangle NA and Perkins SL: Core-binding factor acute myeloid leukemia. Arch Pathol Lab Med 135: 1504-1509, 2011.

21. Appelbaum FR, Kopecky KJ, Tallman MS, Slovak ML, Gundacker HM, Kim HT, Dewald GW, Kantarjian HM, Pierce SR and Estey EH: The clinical spectrum of adult acute myeloid leukaemia associated with corebinding factor translocations. Br J Haematol 135: 165-173, 2006.

22. Kern W, Haferlach T, Schoch C, Loffler H, Gassmann W, Heinecke A, Sauerland MC, Berdel W, Buchner T and Hiddemann W: Early blast clearance by remission induction therapy is a major independent prognostic factor for both achievement of complete remission and long-term outcome in acute myeloid leukemia: data from the German AML Cooperative Group (AMLCG) 1992 Trial. Blood 101: 64-70, 2003.

23. Germing U, Hildebrandt B, Pfeilstöcker M, Nösslinger T, Valent P, Fonatsch C, Lübbert M, Haase D, Steidl C, Krieger O, Stauder R, Giagounidis AA, Strupp C, Kündgen A, Mueller T, Haas R, Gattermann N and Aul C: Refinement of the international prognostic scoring system (IPSS) by including LDH as an additional prognostic variable to improve risk assessment in patients with primary myelodysplastic syndromes (MDS). Leukemia 19: 2223-2231, 2005.

24. Spoo AC, Lübbert M, Wierda WG and Burger JA: CXCR4 is a prognostic marker in acute myelogenous leukemia. Blood 109: 786-791, 2007.

25. Boissel N, Leroy H, Brethon B, Philippe N, de Botton S, Auvrignon A, Raffoux E, Leblanc T, Thomas X, Hermine O, Quesnel B, Baruchel A, Leverger G, Dombret $\mathrm{H}$ and Preudhomme C; Acute Leukemia French Association (ALFA); Leucémies Aiguës Myéloblastiques de l'Enfant (LAME) Cooperative Groups: Incidence and prognostic impact of c-Kit, FLT3, and Ras gene mutations in core binding factor acute myeloid leukemia (CBF-AML). Leukemia 20: 965-970, 2006.

26. Dombret H, Preudhomme $\mathrm{C}$ and Boissel N: Core binding factor acute myeloid leukemia (CBF-AML): is high-dose Ara-C (HDAC) consolidation as effective as you think? Curr Opin Hematol 16: 92-97, 2009. 